\title{
Salt marsh synthesis: local politics, local identity perception and autonomy initiatives on Canvey Island (Essex, UK)
}

\author{
Philip Hayward \\ University of Technology Sydney, Australia \\ Southern Cross University, Lismore, Australia \\ prhshima@gmail.com
}

\begin{abstract}
Canvey Island, located on the north side of the Thames Estuary, has experienced periodic inundations since its earliest periods of settlement. The island was sparsely populated until the late 1800s when a series of developments, including the construction of fixed links to the mainland, attracted migrants from the East End of London who went on to form the core of the present-day population. The recent and relatively homogenous nature of this migration pattern has led to a local perception of difference from the more established communities of the adjacent Essex shore. The latter factor has contributed to a growing push for local autonomy on the island, which has connected with broader national political trends. The article identifies the manner in which experiences and perceptions of insularity can foster distinct senses of local difference and marginalisation that result in autonomy initiatives at grassroots levels. With regard to the latter, parallels are also drawn with previous local autonomy initiatives in the United Kingdom, particularly those of the Isle of Dogs in 1970. The article also emphasises the role of the imagination and representation of locality in promotional, popular cultural and political discourse that informs senses of community identity in various ways.
\end{abstract}

Keywords: autonomy initiatives, Canvey Island, local identity, local politics, Thames Estuary

https://doi.org/10.24043/isj.22

C 2018 - Institute of Island Studies, University of Prince Edward Island, Canada.

\section{Introduction}

Canvey Island comprises $18.5 \mathrm{~km}^{2}$ of partially reclaimed alluvial salt marsh on the north bank of the Thames Estuary. Separated from the Essex mainland by a series of creeks, many areas of the island lie below sea level and are only rendered inhabitable by tidal and storm surge defences that protect a population that has grown from approximately 270 in the late 1800 s to around 38,000 in 2017.

While the majority of Canvey's community lacks a sustained multigenerational association with the island, a strong local identity has developed that derives from five associated factors: a) a general sense of insularity that is common to island populations; b) an awareness of the island's vulnerability to flooding; c) a sense of working-class solidarity (reflecting the community's identification with London's East End as a point of origin and reference); d) a continuing low socioeconomic profile; and-reflecting all the above-e) a sense of neglect by and marginalisation from local and county governments. These aspects have created variously conflicting and complementary senses of place in promotional, popular cultural and political discourses that are also apparent in one of the area's most notable recent phenomena, the rise of a local autonomy movement. This initiative has substantial points of affinity with broader national political movements, most particularly that of the UK Independence Party and its successful advocacy of 'Brexit' (i.e., Britain's withdrawal from membership of the European Union). Reflecting on these aspects, the following sections outline the historical development of regional autonomy initiatives 
within the UK and the manner in which these intersect with the concerns of pro-Brexit lobbyists, profile the historical development of Canvey Island's current community and its representation in locally developed forms of popular culture, and analyse the formation, operation, and key concerns of the Canvey Island Independent Party.

\section{Exit politics and autonomy initiatives}

The people of Canvey voted for Brexit - they would love to Brexit the mainland. (David Blackwell, leader of Canvey Island Independent Party, pers. com., 11 February 2017)

It has been apparent for some time that the United Kingdom (of Great Britain and Northern Ireland) has been anything but united over the last four decades. For that reason, this article will use the term 'UK' throughout when describing the nation state, not just for the convenience of abbreviation of the former term but also as an implicit recognition that the term 'United' is far less appropriate than it may have been at previous historical junctures. As subsequent discussions elaborate, the majority national vote in favour of exit from the European Union (EU) in the 2016 national referendum (decided by $52 \%-48 \%$ ) can be read not so much as a confirmation of a united national identity and cohesion, but as its opposite.

While the UK's national fabric may have held together during the days of Empire, the last sixty years have threatened major internal schisms, with a variety of regions pushing for greater autonomy and, in some cases, independence. The most significant of these has been Scotland (which was a separate nation before being united with England and Wales via the 1707 Acts of Union passed by the parliaments of both nations). Despite the defeat of the Scottish Nationalist Party's (SNP) push for full independence in the 2014 referendum (which was defeated 55-45\%), the resounding vote in favour of staying in the EU recorded in Scotland (62\%-38\%) in the 2016 UK referendum has revived the push for Scottish independence. This is because the SNP regard inclusion within the EU as less marginalising than their inclusion within an isolated nation state dominated by England. While the campaign for Welsh devolution has not secured the regional assembly that Scotland gained in 1999 (nor moved into significant calls for total independence), there have been significant concessions from the UK Government in Westminster (most notably in linguistic and cultural terms, such as the establishment of S4C - the Welsh language TV Channel Sianel Pedwar Cymru—in 1982).

At a county level, the Cornish nationalist party, Mebyon Kernow, may not have achieved the increased autonomy within the UK it has desired and campaigned for since the 1970s. But the broader support for and recognition of local cultural factors that it championed contributed to the county receiving what autonomy activists perceived as de facto regional recognition within the EU. The latter comprised a Cornish seat in the EU Parliament, established in 1979, and targeted project funding from Brussels. This also assisted recognition of Cornwall's residual Celtic language and related cultural identity (affirmed by the Council of Europe's Charter for Regional for Minority Languages) which resulted in active support by the UK Government in 2014 (marking the first ever recognition of this language and identity at a national level), though such support was abruptly terminated in 2016 in the run-up to the EU referendum. Somewhat paradoxically — and, no doubt, gallingly for autonomy activists - the majority of Cornwall voted for Brexit (56.5\%-43.5\%) and, thereby, an end to EU support for Cornish projects.

At more micro levels there have also been several autonomy initiatives that have been premised on senses of local difference, marginalisation, and/or nostalgia for low-crime and socially cohesive and conformist pasts imagined to have existed prior to postwar waves of Commonwealth and European migration to the UK. As discussed in Grydehøj and Hayward (2011), a group of associated autonomy initiatives on the Isle of Wight, off the south coast of the English county of Hampshire, exemplify this characterisation. Far from coincidentally, $62 \%$ of Isle of Wight voters voted for Brexit. Many aspects of the Isle of Wight's autonomy initiatives derive from a more general sense of island insularity that has been identified and elaborated upon by researchers such as Baldacchino $(2006 ; 2010)$ and 
Hay (2006). As discussed in Hayward (2014), islands_-and, particularly, small and low-populated islands-have also been particular centres of variously frivolous or serious (if eccentric) attempts to exit the nation states they operate within and assume independent identities as micro-nations. The impulse for such projects is essentially similar to those discussed above, namely senses of oppression by remote authorities and a desire for local-centric self-management. Two of the most notable of these micro-nations are Forvik, proclaimed on the Shetland island of Forewick Holm in 2008, and Islonia, proclaimed on Dry Island, in the Western Highlands in 2013 (see Grydehøj, 2014; and Hallerton \& Leslie, 2015, respectively). Perhaps the most relevant micro-nation for the purposes of this article was the short-lived Isle of Dogs autonomy campaign in 1970.

The Isle of Dogs is an area on the north bank of the Thames in (what is now) east metropolitan London. Despite its name, it is an alluvial peninsula created by a pronounced meander in the Thames as it flows out towards the English Channel. The marsh/heath area in question resulted from drainage of an area in the north of the present-day Isle of Dogs sometime in the 13th century. A small farming community occupied the area until the embankments were breached in 1448, creating the elongated east-west Poplar Gut lake and adjacent regenerated wetland areas. The watery barrier created at the north of the area appears to have generated the term 'island' for the stretch of peninsula to its south. The southern area became further 'islanded' in the early 1800s as a result of the construction of the West Indian docks at the north of the peninsula and the basins that connected the docks to the Thames on the east and west sides. These facilities required bridges to be constructed to link the southern areas to the north bank of the Thames. Settlements grew up to house the dock workers and their families with the result that the area's population grew from 200-300 in the late 1700s to 14,000 by the mid-1800s (Island History Trust). From the late 1800s on, the isolated position of the communities was exacerbated by the frequent activation of swing-bridges to allow shipping in and out of docks, interrupting traffic flows along the eastern and western waterside roads. Local and national authorities were also widely perceived to have neglected the redevelopment of the Isle of Dogs (and other areas of London's East End) following damage caused by extensive German bombing during World War Two. By the late 1960s the population numbered around 10,000 and the sense of neglect prompted Labour Party councillor Ted Johns to lead a group of local activists to attract media attention to the Isle of Dog's plight by making a Unilateral Declaration of Independence (UDI).

The concept of the UDI had risen to the forefront of British consciousness in the late 1960s following British colony of Rhodesia's declaration of UDI in 1965 and the UDIs also announced (unsuccessfully) for the southeastern Ibo area of Nigeria, as Biafra (1969-1970), and for East Pakistan, which gained independence as the nation of Bangladesh in 1971. In addition to these major political upheavals, the concept was invoked by various groups seeking local advantage and/or autonomy. One particular group who picked up on it were local politicians who were increasingly concerned about the lack of support for the Isle of Dogs community from the Tower Hamlets regional council. Seeking traction from the concept, local activists John Westfallen and Ted Johns coordinated the blocking off of road access to the island and ship access to the sea from the docks for two hours on 1 March 1970. The protest group followed up the event by issuing an announcement: "We have declared UDI and intend to set up our own council. We can govern ourselves much better than they seem to be doing. They have let the island go to the dogs" (Bone, 2009).

The combination of the event and its branding as an act of UDI proved highly effective as political theatre. The potency of UDI as a phenomenon in the late 1960s boosted the symbolic aspect of the blockade and attracted major national and international media coverage. This, in turn, secured the campaign's leaders a meeting with UK Prime Minister Harold Wilson to discuss their grievances and prompted a rapid response from Tower Hamlets Council, who announced a series of measures beneficial to the Isle of Dog's inhabitants. Having achieved its goals of publicising local grievances and securing some favourable measures, the movement quickly dissipated and did not continue into an ongoing local political organisation. It nevertheless represented a high-profile and, in the short term, successful intervention into local politics by the population of an area whose peninsular 'almost-islandness' arguably merited more proactive attention from its administrative authority than had previously been the case. 
The autonomy initiatives that emerged on the Isle of Dogs in the late 1960s and, as will shortly be discussed, Canvey Island in the 2000s and 2010s, were significantly different from those that occurred on the Isle of Wight between the late 1960s and early 2000s in terms of the class position of the activists and of the island communities more generally. While all three appear to have shared a belief in and abiding affection for a "quintessential Englishness" undisturbed by what they perceive as the intrusion of incomers with different ethnicities and cultural inclinations, many key Isle of Wight autonomy advocates have professed a middle- class worldview and inclinations and a somewhat bucolic vision of their regional abode (Grydehøj \& Hayward, 2011, pp. 190-196). In contrast, the most prominent Isle of Dogs and Canvey Island activists have been more oriented to perceptions of the working-class roots of their areas and residents.

\section{Canvey Island: history and context}

Within the scenario sketched above, Canvey Island represents a detail within a national quilt whose threads have been stretched in recent decades, distorting individual designs and wrinkling the symmetries necessary for its recognition as a coherent entity. In this regard, the tiny panel at the bottom right-hand corner of the quilt depicting Canvey Island does not so much represent the greater design in micro but rather is one instance of the heterogeneity of elements represented as coherent but currently in a state of crisis. It is also a panel that sits on the edges of one of the quilt's richest and most ornate designs - one whose size and magnificence dominates a large portion but is also oddly out of fit with other parts - that of London, the UK's economic and institutional heart and one of its most established multicultural cities. As the following sections make apparent, Canvey's panel has, in large part, been fabricated from the off-cuts and discarded threads of London's, reflecting the patchwork identity of the island (itself stitched together from earlier fragments of land).

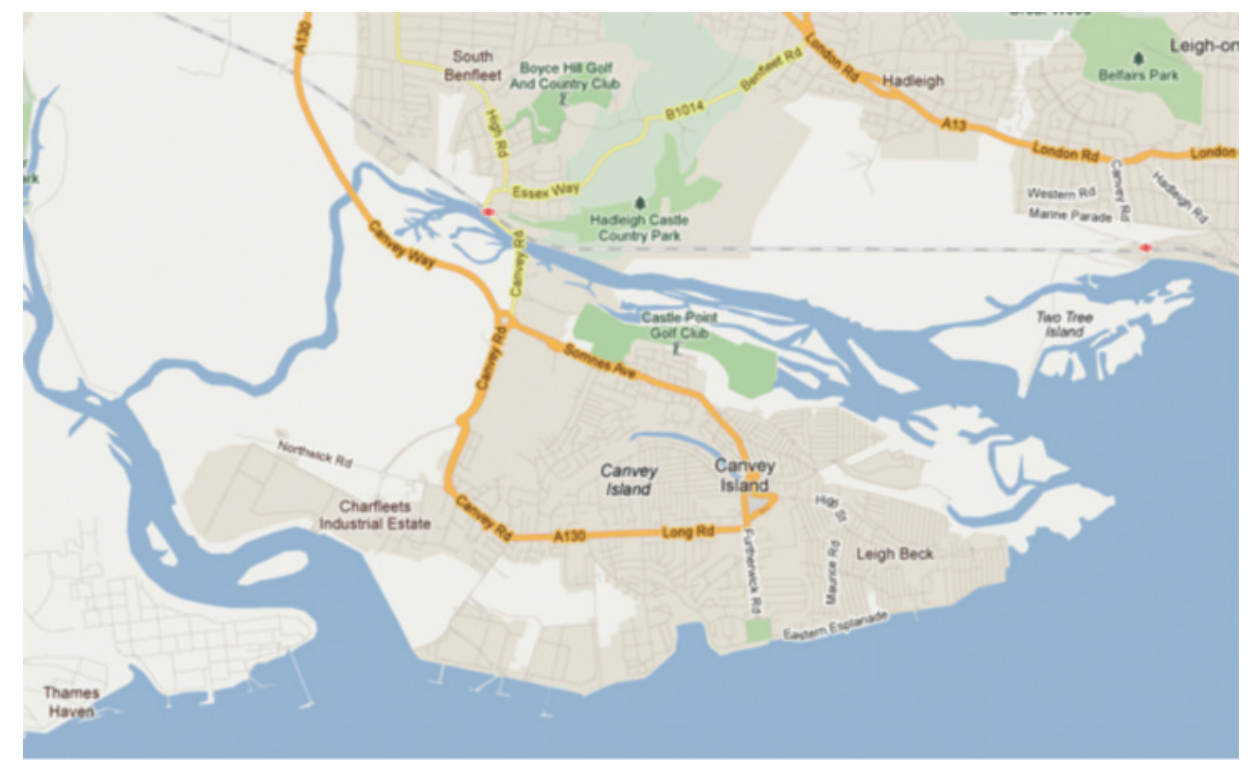

Figure 1: Map of present-day configuration of Canvey.

(Source: http://www.canveyisland.net/wp-content/uploads/2010/12/canvey-map.png)

The Canvey area has been subject to visitation, occupation, and resource utilisation since (at least) the Roman occupation of Britain (approximately $55 \mathrm{BCE}$ to the early 5 th century $\mathrm{CE}$ ) and the Roman's development of Londinium as a trade and administrative centre. Early human uses of the island exploited the area's brackish water ecosystems through oyster cultivation and salt evaporation ponds. The island's frequent flooding during annual 'king tides' and as the result of storm surges may have caused some temporary disruption to these activities but was relatively easily 
accommodated given that the activities were reliant on estuarine water. With the withdrawal of the Romans, the Anglo-Saxons became the dominant power group in the southeast of England and their settlement at Lundenwick, just to the west of the Roman city, developed as the region's major metropolis. Although smaller in population than the Roman centre, rising from about 10,000 around the 4th century to around 25,000 by the 10th, Lundenwick required reliable provisioning, and from the 5th century onwards sheep were farmed in the Canvey area to supply the city. In this period the area "consisted of a large number of small islands" (Rippon \& Wainright, 2011, p. 2). While there is evidence of medieval embankments constructed to prevent flooding, the effects of frequent inundations eventually became so disadvantageous to the agricultural exploitation of the region that in the 1620s local landowners collaborated to address the problem. Inspired by the success of Holland in reclaiming and protecting low-lying areas of land, they employed Dutch specialists to develop protective walls, fill in small waterways, and create drainage ditches so as to produce a stable area for farming. This was a major endeavour, with about 300 Dutch labourers and supervisors being brought in to construct dykes along the coastal margins that delineate today's island. These activities can be perceived as the point at which the unitary space of what is now conceived of as Canvey Island was synthesised (Rippon \& Wainright, 2011, p. 2).

The draining and dyke construction also created a distinct identity for Canvey since many of the workers were paid in blocks of land rather than in cash. Many settled and created distinct Dutch-style dwellings and farms. There was, however, a catch to their land grants in that the families were expected to maintain the seawalls for perpetuity. This-and other factors-caused many Dutch settlers to abandon their lands and return to the Netherlands. The seawalls then fell into disrepair. A series of small floods followed in the 1700s and 1800s, causing damage that resulted in temporary ad hoc repairs. Despite these periodic floods, the island developed as an agricultural centre in the 1700s and 1800s, predominantly servicing London, which grew from a population of 700,000 around 1750 to 2.36 million by 1850, requiring a significant area of southeast England to service its population. With agriculture being the dominant livelihood occupation, the island had a low population density and a total population of around 270 in the late 1800 s.

The major change in the island's socioeconomic base and population density resulted from the introduction of a new industry to the area: tourism. Following the opening of a train line between London and Southend in 1856, the Essex shore became a prime tourism destination for the working-class population of East London, who could (just about) visit the area on a day trip and could more easily spend weekends and short holidays there. Canvey Island was not directly on the rail line but was accessible via ferry from the mainland, and a few adventurous visitors came to experience a quieter, more rural environment than those of the major resort towns. The novelist Robert Buchanan (1901, p. 1) travelled to the island in the late 1890s and wrote about it in his book Andromeda: an idyll of the great river, providing a vivid, if not over-flattering, description of the locale:

Even to-day, when the neighbouring shores of Kent and Essex are covered with new colonies and ever increasing resorts of the tourist, Canvey is practically terra incognita and its one house of public entertainment as solitary and desolate as ever. Flat as a map, so intermingled with creeks and runlets that it is difficult to say where water ends and land begins, Canvey Island lies, a shapeless octopus... and stretches out muddy and slimy feelers to touch and dabble in the deep water of the flowing Thames.

Despite Buchanan's negative perception of the area, other outsiders saw the possibility of capitalising on its environmental assets. The first major project of this kind came in the form of real-estate speculation undertaken by an entrepreneur who sought to profit from the extensive damage to the island caused by a major flood in 1899. Businessman Frederick Hester had a vision of turning Canvey into a lifestyle and holiday destination. Envisioning and marketing the locale as 'Ye Olde Dutch Island', he bought up large areas of farmland, provided basic infrastructure, and then sold plots of land. While the branding of an area of England with a foreign identity was novel in itself, any 
sense of association with the Netherlands' highly successful construction and maintenance of sea-dykes would have been advantageous to marketers given the area's recent flooding issues. Using the income from plot sales, Hestor built various amenities and promised various more, including a pier, but ran out of money. One thing he did not invest in was seawall maintenance, and following floods in 1904 and a lack of substantial return on his investments, his business collapsed in 1905. A number of plot purchasers remained, and by 1920 the population reached around 1,800, with this increasing significantly after the Canvey council funded the building of a bridge to connect Canvey Island to the mainland in 1931. This led to the development of leisure facilities along the island's estuary front, including the Casino Ballroom and Amusement Arcade in 1933 and a number of caravan sites, cafes, and shops. The Ballroom was the island's first licensed music venue and featured popular dance bands on weekends and during weekdays in peak holiday season. These leisure amenities served as a major attractor for both tourists and new residents. A significant proportion of both of these groups came from East London, due to interconnected aspects of proximity and convenience, and prior experience of the island as tourists and/or perceptions of the economic opportunities to be had from servicing a demographic with which new residents were familiar. The rapid urban sprawl of London to the east also made Canvey Island attractive as part of a green and estuarine outer metropolitan fringe. Somewhat contrarily, the establishment of a bridge and its road link on to Canvey also enabled other developments.

An oil terminal was built in the southern area of the island in 1936, creating significant employment but also changing the character of parts of the island. The lack of maintenance of the seawall system came back to bite the area in January 1953 when the so-called 'North Sea Flood' occurred. This comprised a coincidence of a high spring tide and a severe storm that caused surges that flooded areas of the coasts of The Netherlands and Belgium and southeastern England as it was funnelled into the narrow stretch of the Straits of Dover. On Canvey Island 58 people died when water surged in, swamping single-storey buildings in low-lying areas. Extensive work was undertaken to remediate the flooded lands and to strengthen and increase the height of the island's protective walls.

Following the extensive rebuilding of island defences and infrastructures, the population re-established itself and both tourism and industry revived-developing rather uneasily alongside and in relatively close proximity to each other. The most significant industrial element was an Anglo-American project intended to make Canvey Island a major fuel importation and processing centre for the United Kingdom. The first delivery came in the form of 2,000 tons of liquid methane imported from Louisiana in 1959. While this looked likely to be a viable operation, its importance was undermined by the discovery of oil and gas reserves off the North East coast of England that provided a cheaper supply option. Further problems followed. An oil refinery was developed but was then refused permission to operate on safety grounds, resulting in a mile-long jetty being built and then abandoned in 1975 and a major area of half-constructed refinery buildings and storage facilities that have remained standing, disused and decaying. As if this factor were not a significant enough problem for the local tourism industry, another new factor emerged in the mid-1970s, the introduction of cheap overseas air travel packages that allowed working-class families to holiday in places such as Spain at relatively low costs (delivering warmer weather and not requiring them to have to try and enjoy themselves in the shadow of decaying industrial infrastructure). As a result, Canvey Island became a place where only the most budget-orientated holidaymakers went, resulting in diminishing profits and limited and highly seasonal employment opportunities in tourism. Low rents and property prices matched the low socioeconomic status of the majority of the island's residents and combined to give the island a very particular social dynamic - a sense of estrangement from the nearby coast, a sense of economic and geographical outsiderness, and an identity that was very dualistic - very much Canvey-centric but also very much centred on the population considering themselves as being migrant East Londoners.

Local sense of place is also worth emphasising. The seawalls erected after the 1953 floods created an unusual landscape where the coast in several areas was hidden behind high seawalls that loomed above the low internal land and where abandoned industrial buildings overlooked relatively 
unspoiled creeks, salt marshes, and meadows. Local experience of this paradoxical landscape, and of the low socioeconomic status of the community, were interpreted and represented in a striking form in the 1970s with the formation of local rhythm and blues ensemble Dr. Feelgood and the inscription of the band's oeuvre and associations in a variety of audiovisual representations. While only offering a partial reflection of aspects of local experience in the late $20^{\text {th }}$ and early $21^{\text {st }}$ centuries, the prominence of the band's vision of the island in popular culture and the manner in which it has represented the locality merits consideration within the framework of this article.

\section{The Feelgood factor}

Dr. Feelgood was formed in 1971 by four Canvey Island musicians-Lee Brilleaux (lead vocals), Wilko Johnson (guitar), John Sparks (bass guitar), and John Martin (drums). The band was heavily influenced by American rhythm and blues music which they localised with driving rock arrangements, featuring Johnson's highly idiosyncratic riff and rhythm guitar parts, and original songs (mainly written by Johnson) that represented attitudes and scenarios drawn from the highly masculine social milieu from which band members emerged. As British travel writer Chris Somerville (2009, p. 70) characterised:

The songs he wrote presented sharp cameos of cheerful chancers down on their luck, of cheating girls and hard men, citizens of a harsh yet lively town he called Oil City. Each miniature chronicle came across as pungently and economically as a Raymond Carver short story... In Wilko's Oil City, hard-boiled characters watch the refinery towers burning at the break of day as they wait for some red-eyed rendezvous.

From its beginning, the band was promoted as a regional act with a distinctly regional identity. This was inscribed within the lyrics of the title track of their debut album, Down by the Jetty (1975) that, in turn, provided the inspiration for the album's cover image, an atmospheric black-and-white photo of the band looking tough, edgy, unkempt, and wind-blown standing on a jetty with a cargo ship in the background. The band's musical style, lyrical themes, and a particular imagination of place of origin led reviewers and band members to adopt the term 'Thames Delta' to describe Canvey Island and the adjacent Essex coast and, relatedly, the term 'Thames Delta Blues' to describe their sound. The term is, of course, a misnomer. The Thames enters the North Sea via an estuary rather than a delta. But the 'Delta' term was used less in a geographical sense than an allusive one, implicitly aligning the commonly perceived gritty authenticity and invention of Mississippi Delta Blues music typified by musicians such as Robert Johnson, John Lee Hooker, and Muddy Waters (whose material Dr. Feelgood covered in live performance and on record). This particular exercise in place mythologising-which picked up on specific aspects of the locale and represented them as emblematic of that locale-succeeded in creating a particular brand image of the band and their place of origin that has persisted in rock culture and related tourism. The band's particular place mythology was significant in both local and national terms. Locally it performed the somewhat surprising manoeuvre of affirming a distinct sense of community rooted in an East End past with reference to a specifically south eastern US music form and mythology of place. Nationally, the band's oeuvre and iconography was significant for its concentrated inscription and elaboration of local place mythology in songs and associated promotional discourse. Whereas North American culture, for instance, has an extensive body of song lyrics and associated discourse that elaborates place mythology, British popular music has been far more sparing in such references, even when based in a specific location that is prominent in its marketing, such as the Merseybeat Boom of the 1960s (within which prominent inscriptions of place, such as Gerry and The Pacemakers' 'Ferry cross the Mersey' [1965] or The Beatles' more subtly allusive 'Strawberry Fields Forever' [1968] were more the exceptions than the rule.) 
Dr. Feelgood's popularity peaked in 1976 when its live album Stupidity reached number 1 in the UK album charts and declined after Johnson quit the band in 1977. While lead-singer Brilleaux fronted modified band line-ups until his death in 1994, the band's profile in the 1980s and 1990s was markedly lower. But, if anything, Brilleaux's death served to intensify the band's original mythology and to render Canvey Island a place of cultural pilgrimage for fans. This was nurtured through annual Brilleaux memorial concerts on Canvey island, initiated in 1994, and through annual walking tours of the island run by the band's former manager, Chris Fenwick, in which patrons are shown the locations in which original band members grew up and first performed (and an associated exhibition was also held at the Island's Canvey Club in 2013). Anecdotal evidence also suggests that casual tourist visitation to the island outside of the periods in which these events occur has also been influenced by the area's association with the band in its heyday.

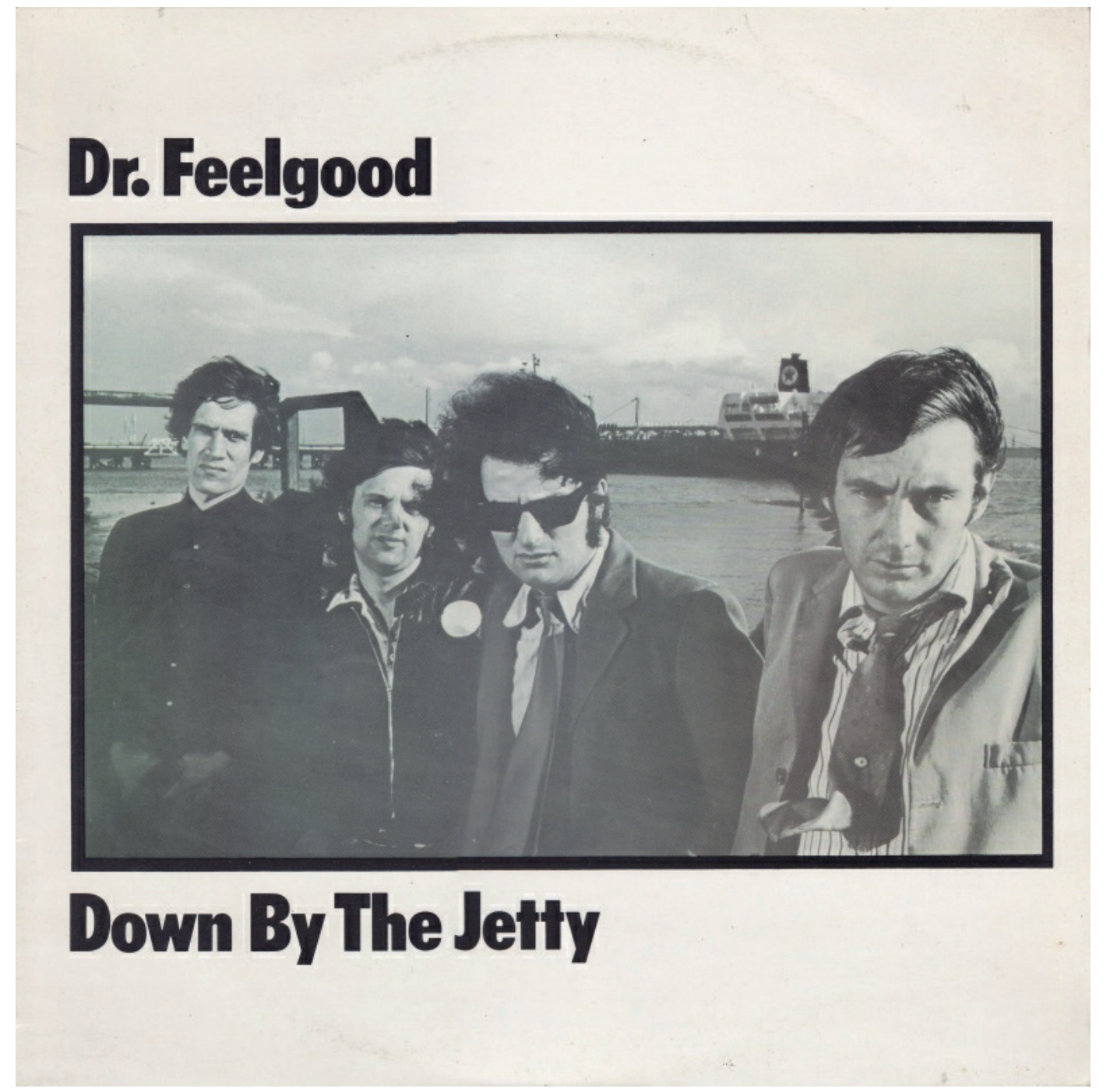

Figure 2: Cover of Dr. Feelgood's debut album Down by the Jetty (1975). (C) Grand Records)

All of the aspects discussed above were also inscribed and amplified in a 2009 feature-length film about the band and their place of origin directed by Julien Temple entitled Oil City Confidential. The film received highly positive reviews and was screened on British national TV and released on DVD. The film is essentially hagiographic, rather than documentary, boosting and enhancing the band's myths of origins in the imagined locale of the film's title, located within the 'Thames Delta' celebrated in the band's songs. Similar aspects were also present in Temple's follow-up 
film, The Ecstasy of Wilko Johnson (2015). Like any myth, the films' images serve to render place and its history through a particular lens. Both films' renditions of Canvey Island are more akin to a perspective that was in critical vogue in the decade before its production, that of hauntology, which Colin Davis (2005, p. 373) has characterised as "the priority of being and presence with the figure of the ghost as that which is neither present, nor absent, neither dead nor alive." In this regard the 'Oil City' Temple that Dr. Feelgood represented in its songs (and that music tourists come to visit) primarily exists within its own representation. Tourism to it is therefore a curious exercise based on re-weaving mythologies of place through visiting and reaffirming the place that inspired those mythologies. Hence the discrepancy with local visions such as those promulgated by the Canvey Island Independent Party, whose place mythologies and senses of investment and performance of space are markedly different in origin, purpose, and articulation.

\section{Perceptions of place, local politics, and associated autonomy initiatives}

Oil City gave the impression that we were a large industrial town but in fact we only have two small calor gas sites and Oikos, the refinery that people think is on Canvey Island, is actually the other side of the water. (CIIP founder David Blackwell, pers. com, 9 February 2017)

The above comment, made by the founder of the Canvey Island Independent Party, emphasises the contested nature of representations of place. While Blackwell is correct in identifying that Canvey Island is not an overwhelmingly industrial space, and that the Oikos refinery is on the opposite bank of the Thames, his characterisation of the "small" nature of the island's calor gas sites is relative, as the facilities have a throughput of around 150,000 tonnes of liquefied petroleum per year (Port of London Authority, 2017, p. 88), making them a major supplier of London's energy needs and "one of the main gas distribution centres for the UK" (Floodsite, 2010).

Senses of place and issues of representation have been key to recent political developments on Canvey. Over the last two decades, in particular, there has been growing local resentment against the dissolution of Canvey Island District Council in 1974. This resulted from the implementation of the UK's 1972 Local Government Act that abolished many local level councils in an attempt to streamline local and regional administration. Since 1974 Canvey Island has been included within Castle Point Borough, along with the mainland towns of Benfleet, Hadleigh, and Thundersley. With an approximate 35\%-65\% split in terms of population and seats, Canvey's voice and concerns became very much minority ones in the new representative body. Continuing local perceptions of the island's distinct local identity and neglect by Castle Point Borough Council crystallised with the formation of the Canvey Island Independent Party (CIIP) in 2004. The party gained immediate electoral success, winning 6 seats in the 2004 Borough elections and going on over the next decade to hold an average 15 of the 16 Canvey Island seats in the Borough (with the Conservative Party holding the rest) and briefly being in power in loose coalition with UKIP in 2014 before the Conservatives regained control of the borough in 2015.

While the 'independent' term in the CIIP's name refers to its independence from established British political parties, it also suggests the party's desire for a greater autonomy for the island it represents. On the CIIP website's main page, for instance, the party's founder and leader makes the following statement:

During the 1950's and 1960's Canvey Island was a lovely place to live; clean and safe. Where has all of that gone? [...] Well it seemed to have started when we joined the main land. (CIIP founder David Blackwell, pers. com, 9 February 2017) 
In a similar vein the party's 'chairlady' Grace Watson states:

I joined this party seven years ago having decided that a change was needed for Canvey Island. I was disillusioned by other parties and Canvey was not looking how I envisaged it would 27 years ago when I moved here [...] Starting as an observer for the first year I soon recognised that this party was the one that could bring good changes to our island and I soon found myself asking for your vote one year later... Nobody knows this island better than the people that live here. Share your vision of Canvey with us and one day we may be able to make it a reality. (CIIP founder David Blackwell, pers. com, 9 February 2017)

Similar to the key activists involved in mobilising the various Isle of Wight pro-autonomy groups discussed in Grydehøj and Hayward (2011), leading figures in the CIIP appear motivated by a disillusionment about contemporary socioeconomic and political developments and the lack of representation of and advocacy for local issues provided by mainstream political parties. There are double layers to this disillusionment. Blackwell's opening statement refers to an imprecise historical point when the island can be imagined to have had a stronger sense of singularity and social cohesion (i.e., "before we joined the main land") and also prior to the opening up of the A130 road-link that both lowered travel time from East London and increased traffic on the island. This primarily offers a more 'Edenic' counterpoint to the present-day reality of the location. This is also apparent in the party's stated commitment to the maintenance of effective 'Green Belt' environmental areas and its recognition of distinct local heritage landscapes:

Canvey Island's Green Belt contains the Historic Landscape created by Dutch Engineers during the 17th Century. Their work to seal Canvey from the sea, and drain the land has left us with a series of dykes and drains forming a pattern work of fields. (Canvey Island Independent Party, NDb)

There is also a strong sense of convergence between CIIP's politics and sense of nostalgia and the politics of UKIP, whose case for Britain's exit from the EU focused on claims concerning the loss of British self-government as a result of membership of the EU, the disproportionate cost/benefit ratio of financial contributions to the EU by UK taxpayers, and a strong desire to limit immigration that might disturb the traditional ethnic make-up of the locale. Reflecting the above-mentioned convergence of interests between UKIP and CIIP, Canvey Island - or rather the Castle Point Borough area-recorded one of the highest pro-exit votes in the UK (74\%) in the national referendum on EU Membership. Demographic figures recorded in the 2011 national Census suggest that local concern over immigration did not so much represent any actual demographic shift away from the traditional Caucasian anglophone culture that has dominated the island (with figures showing 99\% of the local population as English first language speakers, 97\% being born in the UK and 96\% identifying as having English, Scottish, Welsh, or Northern Irish ethnicity (Canvey Island Census Statistics, ND) as an anxiety over potential future developments. Despite the concern about migration central to Canvey's strong vote to exit the $\mathrm{EU}$, there is far less local alarm and/or campaigning concerning what is likely to be the most pressing problem for the island in future years, namely the predicted rise in sea levels resulting from global warming and the likelihood of tidal surges variously swamping and/or bypassing existing coastal defence systems. In one of the many paradoxes of the EU's involvements in UK affairs, this issue was a key focus of the Global Change and Ecosystems priority of the EU's Sixth Framework Programme, involving "managers, researchers and practitioners from a range of government, commercial and research organisations, specialising in aspects of flood risk management" (Floodsite, ND). Amongst its findings the Sixth Framework report found that access roads to Canvey Island would likely be cut at peak tidal times with relatively minor rises in sea levels, hampering evacuation of residents from low-lying areas and "could have significant implications for the national economy" given 
the major calor gas facilities on the island (Floodsite, 2007). More recent research from the Climate Central Organisation has indicated that almost all of Canvey Island would be submerged with as little as a $2^{\circ}$ Celsius rise in global temperatures (see also local media coverage of the story, such as Porter, 2015). While the Canvey Green Belt Campaign has conducted local campaigns over such issues in the late 2000s and early 2010s, there has been limited support from a local population that has shown a far greater inclination to mobilise behind pro-EU exit concerns.

\section{Conclusion}

The CIIP's campaign for greater autonomy for Canvey Island reflects a number of factors. The first is the general sense of insularity experienced by islanders internationally and a fairly common perception that their issues and conditions are not sufficiently perceived and/or addressed by mainland-based bodies responsible for their administration and servicing. A second, more highly specific one, is the effective importation of a majority population with pre-existing senses of class solidarity and experience of socioeconomic change and displacement in the post-World War Two era (as areas of the East End of London were variously redeveloped and/or have seen significant influxes of migrants). These two aspects have intersected in an area whose modern origins lie in reconstructions following flooding in 1899 and 1953 and whose seawall defences are plain to see along the south coast. Yet, despite this, there is a low level of local concern about the global climate change and sea-level rise issues on the island and a far greater address to parochial matters on the part of the island's main representative organisation, the CIIP. In this regard, while the CIIP represents and articulates specific aspects of local sensibilities and senses of place in an effective and popular manner, there is a misfit between engagements with the micro- and macro-levels concerning the sustainability of ongoing terrestrial settlement on the island and an absence of voices adequately addressing the key environmental issues involved. Representations of the island, its history, and essential community are called into play to serve the interests of various groups but also exceed such functionalities. Evocations of Dutch settler heritage, East End roots, Edenic island experiences, and/or perceptions of the locale as an 'Oil City' in the 'Thames Delta' all provide partial perspectives on a physical space synthesised from tidal salt marshes that has been in a continual flux since the earliest phases of settlement and looks likely to experience more as the Holocene era progresses.

\section{Acknowledgements}

Particular thanks to David Blackwell, leader of the Canvey Island Independent Party, and to those Canvey Islanders who requested anonymity for their discussions of Canvey Island topics with me. The interpretations of their views in this article are obviously mine alone. Also to Stephen Rippon for his comments on early history and land reclamation in the area. A previous version of this paper was presented at the 'Islands Cities and Urban Archipelagos' conference held at Hong Kong University in March 2016; thanks to those delegates who gave me useful feedback on the paper.

\section{References}

Baldacchino, G. (2006). Islands, island studies, Island Studies Journal. Island Studies Journal, 1(1), 1-18.

Baldacchino, G. (2010). Island enclaves: offshoring strategies, creative governance, and subnational island jurisdictions. Montreal: McGill University Press.

Bone, I. (2009). March 1st 1970-Isle of Dogs declares independence!. Isle of Dogs—past life, past lives. Retrieved from https://islandhistory.wordpress.com/2013/12/07/it-was-all-a-bit-of-a-joke/

Buchanan, R (1901). Andromeda: an idyll of the great river. Philadelphia: Lippincott. 
Canvey Island Census Statistics (ND). Retrieved from: http://canvey-islandsouth.localstats.co.uk/census-demographics/england/east-of-england/castle-point/canveyisland-south and Ethnic Group statistics at: http://www.ukcensusdata.com/canvey-islandsouth-e05004087/ethnic-group-ct0010\#sthash.128kuYwT.dpbs

Canvey Island Independent Party (NDa). Website. Retrieved from: http://www.canveyislandindependentparty.org.uk

Canvey Island Independent Party (NDb). Canvey Island history. Retrieved from: www.canveyislandindependentparty.org.uk/canveyhistory

Davis, C. (2005). Hauntology, spectres and phantoms. French Studies, 59(3), 373-379. https://doi.org/10.1093/fs/kni143

Floodsite (ND) Executive summary. Retrieved from: http://www.floodsite.net/html/executive summary.htm

Floodsite (2007) Canvey Island. Retrieved from: http://www.floodsite.net/html/cd task17$19 /$ canvey island.html

Grydehøj, A. (2014). Captain Calamity's Sovereign State of Forvik: micronations and the failure of cultural nationalism. Shima, 8(1), 34-48.

Grydehøj, A., \& Hayward, P. (2011). Autonomy initiatives and quintessential Englishness on the Isle of Wight. Island Studies Journal, 6(2), 179-202.

Hallerton, S., \& Leslie, N. (2015). Islonia: micronationality as an expression of island livelihood issues. Shima, 9(2), 1-8.

Hay, P. (2006). A phenomenology of islands. Island Studies Journal, 1(1), 19-42.

Hayward, P. (2014). Islands and micronationality: an introduction. Shima, 8(1), 1-8.

Port of London Authority (2017). Handbook 2017. Retrieved from: https://www.pla.co.uk/assets/plahbook.pdf

Porter, M. (2015) 200 years from disaster? Research states Canvey and Southend could sink. Basildon Canvey Southend Echo, 11 November. Retrieved from: http://www.echonews.co.uk/news/14022107.200 years from disaster Research states Canvey and So uthend could sink/

Rippon, S., \& Wainwright, A. (2011). Our wetland heritage: an integrated approach towards managing coastal landscapes. Arts and Humanities Research Council Knowledge Transfer Fellowship project grant, initial report. Retrieved from:

https://ore.exeter.ac.uk/repository/handle/10036/3030

Somerville, C. (2009). Somerville's travels: journeys through the heart and soul of England. London: AA Publishing.

The Island History Trust (ND). Website. Retrieved from: http://www.islandhistory.org.uk/index.php?p=2 